\title{
Evaluation of Cost Effectiveness of Onibode Fire-Clay for Production of High Quality Refractory Bricks
}

\author{
David Ehigie Esezobor ${ }^{*}$, Friday Ichifu Apeh², Mfon Okon Udo ${ }^{3}$, Mustapha Fabiyi², \\ Enebi Solomon Apeh ${ }^{2}$ \\ ${ }^{1}$ Department of Metallurgical and Materials Engineering, University of Lagos, Lagos, Nigeria \\ ${ }^{2}$ Engineering Materials Research Department, Nigeria Building and Road Research Institute, Ota, Nigeria \\ ${ }^{3}$ Department of Marine Engineering, Federal Collage of Fisheries and Marine Technology, Lagos, Nigeria \\ Email: "esezobordave@yahoo.com
}

Received 10 July 2015; accepted 23 August 2015; published 26 August 2015

Copyright (C) 2015 by authors and Scientific Research Publishing Inc.

This work is licensed under the Creative Commons Attribution International License (CC BY).

http://creativecommons.org/licenses/by/4.0/

\section{(c) (i) Open Access}

\section{Abstract}

In establishing a plant or factory, the cost-benefit analysis is needed to determine the viability for such financial investment on the project. In this paper, the cost establishing a factory of 200,000 bricks per annum capacity, for the production of high quality refractory bricks from locally available raw materials in Nigeria was evaluated. The evaluation was conducted on the virgin refractory material $(100 \%)$ as well as with varied percentages $(10 \%-40 \%)$ of alumina additions. The result of cost benefit analysis indicated that, the project was viable, with the highest cost at $\mathrm{N1}, 203.66$ per brick as against N1,800 (at 3 years projections) of the imported brick. The payback period for the capital investment was very short (within two years). The findings will aid investors in decision makings.

\section{Keywords}

Cost-Benefit-Analysis, High-Temperature, Refractory Bricks, Steel Plants

\section{Introduction}

In Nigeria, numerous research works [1] [2] had been carried out on the characterization of indigenous refractory raw materials for possible production of quality refractory bricks for furnaces, kilns, ovens, etc., lining to replace the high cost of imported bricks. The effect of alumina addition on the refractoriness and other properties of some fire-clays for their application as furnace linings indicated that high quality refractory bricks can be produced

\footnotetext{
*Corresponding author.
} 
domestically [3]. Regrettably, \$229 million is expended annually to import these materials into the country [4]. Various authors [2] [5]-[7] argued that, this huge spending could be avoided if the bricks were produced domestically in Nigeria.

These refractory materials play a very significant role in the high temperature environments, especially, in furnace linings and construction and other applications. They have wide applications in iron and steel plants, foundries, cement factories, petrochemical industries, etc. The cost of the raw materials, processing and cost of labor for their production have economic or financial input. The viability of economic investment for such endeavor is needed to be established.

In carrying out the economic decisions, a cost benefit analysis is needed to be done in order to determine how well or how poorly a planned action will turn out [8]. Although a cost benefit analysis can be used for almost anything, it is most commonly done on financial analysis [6].

Cost-Benefit Analysis (CBA), also called Benefit Cost Analysis (BCA), is a systematic process for calculating and comparing cost and benefits of a project decision and this has two purposes:

1) to determine if it is a profitable investment and decision (feasibility);

2) to provide a basis for comparing projects, which involves comparing the total expected cost of each option against the total expected benefits, to see whether the benefits outweighed the cost and by how much is this.

In CBA, benefits and costs are expressed in monetary terms and are adjusted for the time value of money, so that all flows of benefits and project cost over time are expressed on a common basis in terms of their "net present value". If the discounted present value of the benefits exceeds the discounted present value of the costs then the project is worthwhile. This is equivalent to the condition that the net benefit must be positive. Another equivalent condition is that the ratio of the present value of the benefits to the present value of the costs must be greater than one.

In financial analysis, financial ratios and efficiency ratios are used as an index or yardstick for evaluating the financial position of a firm. It assists to indicate the strength and weakness of the firm or project. Using the yearend balance sheet figures and other relevant data, the return on sales for instance is computed by dividing the net income by revenue, while return on investment is the net profit plus interest divided by total investment [9].

This paper evaluates the investment benefit of establishing a plant for the production of refractory bricks with a capacity of 200,000 bricks per annum in Nigeria from locally available raw materials.

\section{Methodology}

\subsection{Materials and Description}

The paper envisages the establishment of a plant/factory for the production of high quality refractory bricks with a capacity of 200,000 bricks per annum. The principal raw materials required for the production of these refractory bricks are locally available in Nigeria. The raw materials used for this work include, fire-clay materials and alumina obtained from Onibode, Ogun State South West Nigeria and Aluminum Smelting Company of Nigeria, Ikot Abasi, Akwa-Ibom State, South-South Nigeria respectively.

The as-received materials were characterized in accordance with ASTM C27-98 (2008) [10] to determine their suitability for the production of refractory fire-bricks and the economic viability of the establishment of a factory was evaluated on various options. Bricks with hundred percent (100\%) of the Onibode material collected as well as with the additive material (10\% - 40\% alumina) in various volume fractions of 90:10; 80:20; 70:30 and 60:40 were developed using standard techniques. The cost effectiveness was evaluated on the various developed refractory bricks.

\subsection{Production Route/Process}

\section{Materials Preparation}

The as received materials were crushed in a jaw crusher and ground in a $10 \mathrm{HP}$ grinding machine. The pulverized clay and alumina were mixed with adequate water content in $100 \mathrm{~kg}$ capacity mixer. The mixes were later formed into standardized bricks using a hydraulic compressing machine of 1000 - 1100 bricks per day. The bricks after curing were indurated in a gas fired furnace of $1800^{\circ} \mathrm{C}$.

\subsection{Fixed Assets}

For the purpose of this study, a plot of land measuring $60 \mathrm{~m} \times 120 \mathrm{~m}$ with building structures occupying $45 \mathrm{~m} \times$ 
$100 \mathrm{~m}$ within the plot was used for the evaluation.

\subsection{Evaluation of the Cost Estimates for Refractory Bricks Production}

The financial cost of producing bricks can be equated to the sum of four components of the cost of an imported bricks, i.e., the Cost Insurance and Freight (CIF) price, Tariffs/Taxes and Subsidies, the Trade Margins of importers, and the costs of freight and transportation costs from the port to the warehouse. The data in Table 1 was used as baseline for the calculation.

However, there is a need to evaluate the real unit cost of the locally produced refractory bricks taken into consideration all the equipment needed for its production as well as to determine the unit of account.

\subsubsection{The Unit of Account}

In nearly all economies, domestic market prices are higher than world market price levels which may be caused by exchange controls, import quotas and other trade restrictions [11]. This creates a need to bring all resource inputs to a common basis, so that they can be aggregated into an estimate of the costs of production. It is necessary therefore, to define a unit of account, which involves choosing a price level, domestic or world market price level and choosing a currency that is either national or foreign in which to express all resource inputs. Other information was derived from Table 2.

Five different sizes or types of the bricks were considered and with the varied percentage addition of alumina in the production in order to come up with the economic cost of the refractory bricks. (The alumina was used to improve the refractory properties of the bricks) [4]. For this calculation, 842 tons of clay at N8000 per ton and 206 tons of alumina at N190,000 per ton were used and the sizes of the bricks selected for the calculation are as follow:

Type 1—9" × 21/4" × 21/2"; Type 2—9" × 31/2" × 21/2"; Type 3-9" × 41/2" × 2"; Type 4—9" × 41/2" × 21/2"; Type 5-9" $\times$ 41/2" $\times 11 / 2 "$ as in Table 3 .

Working Capital will be $=$ N76, 220,000 (assuming the market sells ideally and recovery is a year). Otherwise,

Working capital $=$ asset $+($ liability $\times 2)$.

Liability:

The total liability will be twice the sum of the cost of Labor, Maintenance Cost, Raw materials and Energy for two years.

Asset:

The assets include the sum of the cost of Building, Machine/items and the Working Capital.

NOTE: Supervisor is placed on grade level 7 step 4 (HND with minimum of 2 years' experience).

General Manager is placed on level 7 step 5 (B.Sc. with minimum of 3 years' experience).

Administration and Finance Heads are on level 7 step 4 (HND with minimum of 3years experience). Operator: Grade level 6 step 4 (ND with minimum of 2 years experience).

Carriers and mixers are on daily pay of N2000 per day.

Table 1. The estimation of unit economic cost of imported brick.

\begin{tabular}{cccc}
\hline \multicolumn{2}{c}{ Financial cost of imported brick } & \multicolumn{2}{c|}{ Economic cost of refractory brick } \\
\hline & $\mathrm{N}: \mathrm{K}$ & $\mathrm{N}: \mathrm{K}$ \\
\hline CIF price (cost insurance and freight) & 850.00 & 850.00 \\
Tariff (45\% of CIF) & 385.50 & - & - \\
VAT (5.0\% of CIF) & 42.50 & (66.7\% of trade margin) & 198.43 \\
Trade margin (35.0\%) & 297.50 & (66.7\% of freight) & 149.74 \\
Freight & 224.50 & Total & $\mathbf{1 1 9 8 . 1 7}$ \\
\hline Total & $\mathbf{1 8 0 0 . 0 0}$ & \\
\hline
\end{tabular}

Sources: Adeniyi, 2004; Tax Act, 2004 [8]. Where, CIF: Cost Insurance and Freight; VAT: Value Added Tax Act 2004, is taken as 5\% of cost price. 
Table 2. Initial data for evaluation of the 200,000 bricks annual production cost of the refractory bricks (production information).

\begin{tabular}{|c|c|c|c|c|c|}
\hline $\mathrm{S} / \mathrm{N}$ & Information & Description & Cost $(=\mathrm{N}=)$ & Total $(=\mathrm{N}=)$ & Accumulated sum $(=\mathrm{N}=)$ \\
\hline \multirow{3}{*}{1} & \multirow{3}{*}{ Raw materials } & Clay (842-tons) & 8000/ton & $6,736,000$ & \\
\hline & & Alumina (206-tons) & $190,000 /$ ton & $39,140,000$ & \\
\hline & & Sub-Total & & $45,876,000.00$ & $45,876,000.00$ \\
\hline \multirow{4}{*}{2} & \multirow{4}{*}{ Energy } & Electricity (N27/kWhr) 2 machines & $162,000.00$ & & \\
\hline & & Diesel (N150/ltr) (stndby) & $2,160,000.00$ & & \\
\hline & & Gas (N224/kg) & $4,480,000.00$ & & \\
\hline & & Sub-Total & & $6,802,000.00$ & $52,678,000.00$ \\
\hline \multirow{12}{*}{3} & \multirow{12}{*}{ Machines/items } & $\begin{array}{l}\text { Compressing machine } \\
(1000 \text { bricks/day }) \times 2\end{array}$ & $1,700,000.00$ & & \\
\hline & & 100 kvA generator & $3,000,000$ & & \\
\hline & & $\begin{array}{l}\text { Wheel barrow (50 kg), } \\
\text { Shovel, Trowel, etc. }\end{array}$ & $20,000.00$ & & \\
\hline & & Furnace & $1,200,000.00$ & & \\
\hline & & Pallet & $300,000.00$ & & \\
\hline & & Thermo couple & $40,000.00$ & & \\
\hline & & Grinding machine & $45,000.00$ & & \\
\hline & & Weigh scale & $15,000.00$ & & \\
\hline & & Rammer & $20,000.00$ & & \\
\hline & & Furniture and equipment & $450,000.00$ & & \\
\hline & & Maintenance/repair cost & $339,500.00$ & & \\
\hline & & Sub-Total & $7,129,500.00$ & & $59,807,500.00$ \\
\hline \multirow{4}{*}{4} & \multirow{4}{*}{ Building } & Land & $1,000,000.00$ & & \\
\hline & & Building & $2,500,000.00$ & & \\
\hline & & Civil work & $1,000,000.00$ & & \\
\hline & & Sub-Total & & $4,500,000.00$ & $64,307,500.00$ \\
\hline \multirow{14}{*}{5} & \multirow{13}{*}{$\begin{array}{c}\text { Labor } \\
\text { (production) } \\
\text { labor } \\
\text { (fin \& admin) }\end{array}$} & Supervisor (1) & $780,000.00$ & & \\
\hline & & Operator (2) & $1,000,000.00$ & & \\
\hline & & Carrier (4) & $1,600,000.00$ & & \\
\hline & & Mixer (2) & $800,000.00$ & & \\
\hline & & QC/Lab officer (1) & $500,000.00$ & & \\
\hline & & GM (1) & $1,200,000.00$ & & \\
\hline & & Secretary (1) & $400,000.00$ & & \\
\hline & & Head (finance) (1) & $800,000.00$ & & \\
\hline & & Head (admin) (1) & $800,000.00$ & & \\
\hline & & Store man (1) & $450,000.00$ & & \\
\hline & & Gen service (4) & $1,200,000.00$ & & \\
\hline & & Workers' benefit & $2.382,500.00$ & & \\
\hline & & Sub-Total & $11,912,500.00$ & $11,912,500.00$ & \\
\hline & Grand-Total & & & & N76,220,000.00 \\
\hline
\end{tabular}


Table 3. Cost estimates for various volume fractions of clay samples.

\begin{tabular}{|c|c|c|c|c|c|c|}
\hline \multirow{3}{*}{ Type of brick } & \multirow{3}{*}{ Information } & \multicolumn{5}{|c|}{ Cost (N) } \\
\hline & & \multirow{2}{*}{$100 \%$ clay } & \multicolumn{4}{|c|}{ Clay:alumina (\%) } \\
\hline & & & $90: 10$ & $80: 20$ & $70: 30$ & $60: 40$ \\
\hline \multirow{6}{*}{ Type 1} & Building & $4,500,000$ & $4,500,000$ & $4,500,000$ & $4,500,000$ & $4,500,000$ \\
\hline & Machine & $7,129,500$ & $7,129,500$ & $7,129,500$ & $7,129,500$ & $7,129,500$ \\
\hline & Energy & $6,802,000$ & $6,802,000$ & $6,802,000$ & $6,802,000$ & $6,802,000$ \\
\hline & Materials & 3,392,000 & $10,352,000$ & $15,492,000$ & $18,962,000$ & $31,810,000$ \\
\hline & Labor & $11,912,500$ & $11,912,500$ & $11,912,500$ & $11,912,500$ & $11,912,500$ \\
\hline & Total & $33,736,000$ & $40,696,000$ & $45,836,000$ & $49,306,000$ & $62,154,000$ \\
\hline \multirow{6}{*}{ Type 2} & Building & $4,500,000$ & $4,500,000$ & $4,500,000$ & $4,500,000$ & $4,500,000$ \\
\hline & Machine & $7,129,500$ & $7,129,500$ & $7,129,500$ & $7,129,500$ & $7,129,500$ \\
\hline & Energy & $6,802,000$ & $6,802,000$ & $6,802,000$ & $6,802,000$ & $6,802,000$ \\
\hline & Materials & $5,248,000$ & $15,846,000$ & $23,698,000$ & $28,994,000$ & $32,106,000$ \\
\hline & Labor & $11,912,500$ & $11,912,500$ & $11,912,500$ & $11,912,500$ & $11,912,500$ \\
\hline & Total & $35,592,000$ & $46,208,000$ & $54,042,000$ & $59,338,000$ & $62,450,000$ \\
\hline \multirow{6}{*}{ Type 3} & Building & $4,500,000$ & $4,500,000$ & $4,500,000$ & $4,500,000$ & $4,500,000$ \\
\hline & Machine & $7,129,500$ & $7,129,500$ & $7,129,500$ & $7,129,500$ & $7,129,500$ \\
\hline & Energy & $6,802,000$ & $6,802,000$ & $6,802,000$ & $6,802,000$ & $6,802,000$ \\
\hline & Materials & $5,408,000$ & $16,346,000$ & $24,372,000$ & $30,016,000$ & $33,112,000$ \\
\hline & Labor & $11,912,500$ & $11,912,500$ & $11,912,500$ & $11,912,500$ & $11,912,500$ \\
\hline & Total & $35,752,000$ & $46,690,000$ & $54,716,000$ & $60,360,000$ & $63,456,000$ \\
\hline \multirow{6}{*}{ Type 4} & Building & $4,500,000$ & $4,500,000$ & $4,500,000$ & $4,500,000$ & $4,500,000$ \\
\hline & Machine & $7,129,500$ & $7,129,500$ & $7,129,500$ & $7,129,500$ & $7,129,500$ \\
\hline & Energy & $6,802,000$ & $6,802,000$ & $6,802,000$ & $6,802,000$ & $6,802,000$ \\
\hline & Materials & $6,736,000$ & $20,308,000$ & $30,358,000$ & $37,330,000$ & $41,604,000$ \\
\hline & Labor & $11,912,500$ & $11,912,500$ & $11,912,500$ & $11,912,500$ & $11,912,500$ \\
\hline & Total & $37,080,000$ & $50,652,000$ & $57,624,000$ & $64,596,000$ & $68,870,000$ \\
\hline \multirow{6}{*}{ Type 5} & Building & $4,500,000$ & $4,500,000$ & $4,500,000$ & $4,500,000$ & $4,500,000$ \\
\hline & Machine & $7,129,500$ & $7,129,500$ & $7,129,500$ & $7,129,500$ & $7,129,500$ \\
\hline & Energy & $6,802,000$ & $6,802,000$ & $6,802,000$ & $6,802,000$ & $6,802,000$ \\
\hline & Materials & $4,060,000$ & $12,416,000$ & $18,370,000$ & $22,520,000$ & $25,032,000$ \\
\hline & Labor & $11,912,500$ & $11,912,500$ & $11,912,500$ & $11,912,500$ & $11,912,500$ \\
\hline & Total & $31,326,000$ & $39,682,000$ & $45,636,000$ & $49,786,000$ & $52,298,000$ \\
\hline
\end{tabular}

Electricity: N27 per kwhr (this is calculated for 2 machines (12hrs per day) plus 25\% of other loads lighting, computers, fans, etc.).

Diesel: calculation is based on N150 per liter at 201 liters per hour consumption for 30\% power failure).

Gas: based on 2 hours daily at N224 per kg and consumption of $50 \mathrm{~kg}$ per hour. 
Clay is N40,000 per 5 tons (or N8000/ton).

In order to come up with the economic cost of the refractory bricks, five different sizes and types of the bricks were considered as well as the percentage addition of alumina in the production. For this calculation, a 842-tons of tipper load of clay at N8000 and 206 tons of alumina at N190,000 per ton were used based on the following fractions 100:0 clay; 90:10; 80:20; 70:30 and 60:40 and the types of block(s), (Table 3).

\subsubsection{Evaluation Techniques}

The production cost of the brick per annum can be expressed as;

Production cost/year $=$ Building cost + Machine cost + Energy cost + Labor cost + Materials cost;

$$
\left(P_{c}\right)_{y r}=B_{c}+M_{c}+E_{c}+L_{c}+M t_{c}
$$

But, Building cost $\left(B_{c}\right)+$ Machine cost $\left(M_{c}\right)+$ Energy cost $\left(E_{c}\right)+$ Labor cost $\left(L_{c}\right)$ are equal for all production process for any types of the brick size.

Hence,

$$
B_{c}+M_{c}+E_{c}+L_{c}=K_{1} \quad \text { (constant cost) }
$$

Production cost/year $=$ constant cost + Material cost where, $K_{1}=30,344,000$ (Table 2).

The result of the estimation of the production cost is displayed in Figure 1.

$$
\begin{aligned}
\text { Total cost } & =\text { Production cost } / \text { year }+ \text { Other cost addition }(10 \% \text { PC }) \\
& =\text { production cost per year }+0.1 \text { production cost per year }
\end{aligned}
$$

Production quantity per year $=$ Machine capacity per day $\times$ working days (in a year) $=1000 \times 200=200,000$ $\left(K_{2}\right), K_{2 \text { prod.cap }}=200,000$.

Unit Cost $=$ Total Cost $/ K_{2}$.

Handling Cost $=$ Unit Cost.

Selling price $=$ unit cost + handling cost.

Assuming, production cost/year, material cost, total cost, unit cost, handling cost and selling price, are $a, b, c$, $d, e$ and $f$ respectively.

From the above, the following relationship can be established,

$a=K_{1}+b$ and $c=1.1 a$

Thus, it implies that,

$$
d=c / K_{2}, f=d+e
$$

since, $e=d, f=2 d=2 c / K_{2}$

In general form,

$$
f_{i j}=2 c_{i j} / K_{2}
$$

where $i, j$ are the size of the bricks $(a, b, c, d, e)$ and type of bricks in terms of clay/alumina ratio respectively.

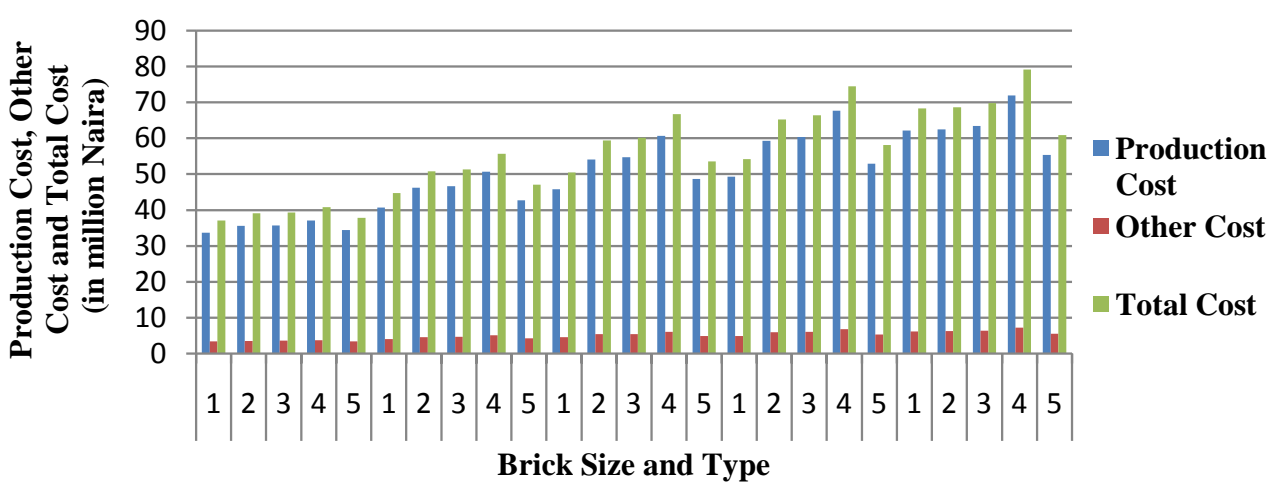

Figure 1. Production cost, other cost and total cost against brick size and type. 
Selling price projection is given by:

$$
F_{v}=A(1+r)^{n}
$$

where,

$F_{v}$ is the future value, $A$ is the present value (which is the current selling price), $r$ is the inflation rate (15\%), $n$ is the year(s), but, $A$ is the selling price $=f$.

Let $F_{v}$ be written as $P_{n}$, $A$ be written as $f$ then,

$$
P_{n}=f(1+r)^{n}
$$

but, $f=2 c_{, j} / K$ and $c=1.1 a$, while, $a=K_{1}+b$, then,

$$
\begin{gathered}
f=2(1.1 a) / K_{2}=2.2\left(K_{1}+b\right) / K_{2} \\
P_{n}=2.2\left(K_{1}+b\right) / K_{2}(1+r)^{n} \\
P_{(i, j) n}=2.2\left(K_{1}+b_{i, j}\right) / K_{2}(1+r)^{n}
\end{gathered}
$$

Break-Even analysis of a firm is calculated thus; $B_{E}=$ Fixed Cost/(Selling price - Unit Cost).

Fixed Cost $=$ N23,542,000 (machinery/items + labor + land and building).

The evaluation of the projected value of the bricks at $15 \%$ inflation rate was performed using equation 11 [1].

$$
F_{v}=A(1+r)^{n}
$$

where, $F_{v}$-future value; $A$-present value; $r$-inflation rate; $n$-year(s).

Viability or otherwise of domestically produced refractory bricks using cost benefit analysis can be expressed as follows;

$$
\text { Cost Benefit Analysis }=\frac{\text { Estimated Relevant Cost of Production }}{\text { Benefit }(\text { Relevant Cost } / \text { Expenses to be avoided })}
$$

In this paper, the cost of importation is valued at USD 229,060,000 [4], while the 2014 exchange rate for 1 USD is 190.00 Naira [11].

Therefore, the cost to be avoided $=$ Expenses on importation will be the product of cost of importation and the current exchange rate.

$$
\begin{aligned}
& \qquad C B A=\frac{N 74,220,000 \times 365 \text { days }}{N 43,521,695,260}=0.622 \text { day for low cost bricks } \\
& \text { Using the highest cost, CBA }=\frac{N 158,284,000 \times 365 \text { days }}{N 43,521,695,260}=1.33 \text { days for highest cost bricks }
\end{aligned}
$$

The formulae above were derived for the various calculations made and the results were tabulated to prepare a five-year reference table for Onibode fire-clays bricks production.

\section{Results and Discussion}

Refractory bricks produced from the low grade fire-clay have the least price of N371.10 for the first year and N564.39 in the third year projection (type "a" 1), while the highest price was N791.43 for the first year and N1,203.66 in the third year (type "e" 4) for high grade fire-clay, as displayed in Figure 2.

The result from the analysis as shown in Figure 2 revealed that, the ultimate effect of increasing the domestic production of a traded input is to reduce imports. The economic benefit of such an endeavor is the economic resources saved from the reduced imports. From the figure, it was discovered that the unit price of the locally produced brick is far lower than the imported brick. Figure 3 showed the result of the estimation of the selling price of the bricks based on three years projection at $15 \%$ inflation rate which is also lower than imported ones, while Table 4 is the 5-years summary of the financial implication of the project. 


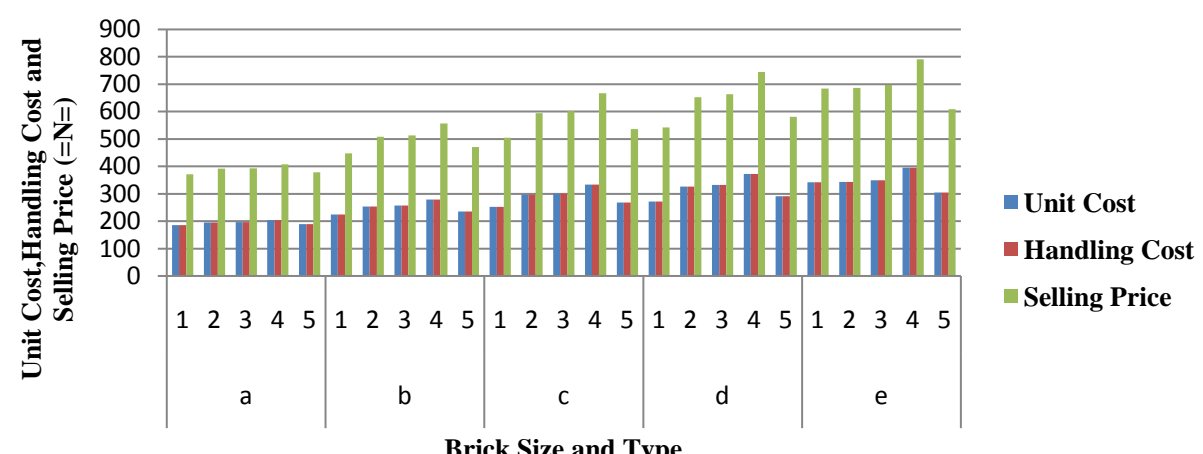

Figure 2. Unit cost, handling cost and selling price against brick size and type (NB: Days per year, machine capacity and quantity of bricks per year are kept constant).

Table 4. Summary of calculation including five years projection plan.

\begin{tabular}{|c|c|c|c|c|c|c|c|c|c|c|c|c|}
\hline \multirow[t]{2}{*}{ Size } & \multirow[t]{2}{*}{ Type } & \multirow[t]{2}{*}{$\mathrm{K}_{1}$} & \multirow[t]{2}{*}{$\mathrm{K}_{2}$} & \multirow[t]{2}{*}{$\begin{array}{l}\text { MAT } \\
\text { COST } \\
(=N=)\end{array}$} & \multirow[t]{2}{*}{$\begin{array}{l}\text { PROD. } \\
\text { COST } \\
(=\mathrm{N}=)\end{array}$} & \multirow[t]{2}{*}{$\begin{array}{l}\text { TOTAL } \\
\text { COST } \\
(=\mathrm{N}=)\end{array}$} & \multirow[t]{2}{*}{$\begin{array}{l}\text { USP } \\
(=\mathrm{N}=)\end{array}$} & \multicolumn{5}{|c|}{$\begin{array}{l}\text { Yearly selling price projection } \\
\text { (15\% annual inflation) }\end{array}$} \\
\hline & & & & & & & & YR1 & YR2 & 3 & YR4 & R5 \\
\hline \multirow[t]{5}{*}{ a } & 1 & $30,344,000$ & 200,000 & $3,392,000$ & $33,736,000$ & $37,109,600$ & 371.10 & 426.76 & 490.77 & 564.39 & 649.05 & 746.41 \\
\hline & 2 & $30,344,000$ & 00,000 & $5,248,000$ & $35,592,000$ & $39,151,200$ & 39151 & 450.24 & 517.78 & 595.44 & 684.76 & 787.47 \\
\hline & 3 & $30,344,000$ & 200,000 & $5,408,000$ & $35,752,000$ & $39,327,200$ & 393.27 & 452.26 & 520.10 & 598.12 & 687.84 & 791.01 \\
\hline & 4 & $30,344,000$ & 200,000 & $6,736,000$ & $37,080,000$ & $40,788,000$ & 407.88 & 469.06 & 539.42 & 620.33 & 713.38 & 820.39 \\
\hline & 5 & $30,344,000$ & 200,000 & $4,060,000$ & $34,404,000$ & $37,844,400$ & 378.44 & 435.21 & 500.49 & 575.57 & 661.90 & 761.19 \\
\hline \multirow[t]{5}{*}{$\mathrm{b}$} & 1 & $30,344,000$ & 200,000 & $10,352,000$ & $40,696,000$ & $44,765,600$ & 447.66 & 514.80 & 592.03 & 680.83 & 782.95 & 900.40 \\
\hline & 2 & $30,344,000$ & 200,000 & $15,846,000$ & $46,190,000$ & $50,809,000$ & 508.10 & 584.30 & 671.95 & 772.74 & 888.65 & 1021.95 \\
\hline & 3 & $30,344,000$ & 200,000 & $16,346,000$ & $46,690,000$ & $51,359,000$ & 513.60 & 590.63 & 679.22 & 781.11 & 898.27 & 1033.01 \\
\hline & 4 & $30,344,000$ & 200,000 & $20,308,000$ & $50,652,000$ & $55,717,200$ & 557.17 & 640.75 & 736.86 & 847.39 & 974.90 & 1120.67 \\
\hline & 5 & 44,000 & 00,000 & 12,41 & 42 & 000 & 4 & 1 & 622.05 & 715.36 & 822.66 & 946.06 \\
\hline \multirow[t]{5}{*}{ C } & 1 & $30,344,000$ & 200,000 & $15,492,000$ & $45,836,000$ & $50,419,600$ & 504.20 & 579.83 & 666.80 & 766.82 & 881.84 & 1014.12 \\
\hline & 2 & $30,344,000$ & 200,000 & $23,698,000$ & $54,042,000$ & $59,446,200$ & 594.46 & 683.63 & 786.18 & 904.10 & 1039.72 & 1195.68 \\
\hline & 3 & $30,344,000$ & 200,000 & $24,372,000$ & $54,716,000$ & $60,187,600$ & 601.88 & 692.16 & 795.98 & 915.38 & 1052.69 & 1210.59 \\
\hline & 4 & $30,344,000$ & 200,000 & $30,358,000$ & $60,702,000$ & $66,772,200$ & 667.72 & 767.88 & 883.06 & 1015.52 & 1167.85 & 1343.03 \\
\hline & 5 & $30,344,000$ & 200,000 & $18,370,000$ & $48,714,000$ & $53,585,400$ & 535.85 & 616.23 & 7 & 77 & 37.21 & 1077.79 \\
\hline \multirow[t]{5}{*}{$\mathrm{d}$} & 1 & $30,344,000$ & 200,000 & 2,000 & 49,30 & 600 & 542.37 & 623.72 & 717.28 & 37 & 60 & 1090.89 \\
\hline & 2 & $30,344,000$ & 200,000 & $28,994,000$ & $59,338,000$ & $65,271,800$ & 652.72 & 750.63 & 863.22 & 992.70 & 1141.61 & 1312.85 \\
\hline & 3 & $30,344,000$ & 200,000 & $30,160,000$ & $60,360,000$ & $66,396,000$ & 663.96 & 763.55 & 878.09 & 1009.80 & 1161.27 & 1335.46 \\
\hline & 4 & $30,344,000$ & 200,000 & $37,330,000$ & $67,674,000$ & $74,441,400$ & 744.41 & 856.08 & 984.49 & 1132.16 & 1301.99 & 1497.28 \\
\hline & 5 & $30,344,000$ & 200,000 & $22,520,000$ & $52,864,000$ & $58,150,400$ & 581 & 668.73 & 769.04 & 884.39 & 1017.05 & 1169.61 \\
\hline \multirow[t]{5}{*}{ e } & 1 & 000 &, 000 & 000 & 62 & 00 & $0 c^{2}$ & 7 & 19 & 10 & 79 & 13 \\
\hline & 2 & $30,344,000$ & 200,000 & $32,106,000$ & $62,450,000$ & $68,695,000$ & 686.95 & 789.99 & 908.49 & 1044.77 & 1201.48 & 1381.7 \\
\hline & 3 & $30,344,000$ & 200,000 & $33,112,000$ & $63,560,000$ & $69,801,600$ & 698.02 & 802.72 & 923.13 & 1061.60 & 1220.83 & 1403. \\
\hline & 4 & $30,344,000$ & 200,000 & $41,604,000$ & $71,948,000$ & $79,142,800$ & 791.43 & 910.14 & 1046.66 & 1203.66 & 1384.21 & 1591.84 \\
\hline & 5 & $30,344,000$ & 200,000 & $25,032,000$ & $55,376,000$ & $6,091,600$ & 609.14 & 700.51 & 805.58 & 926.42 & 1065.38 & 1225.19 \\
\hline
\end{tabular}




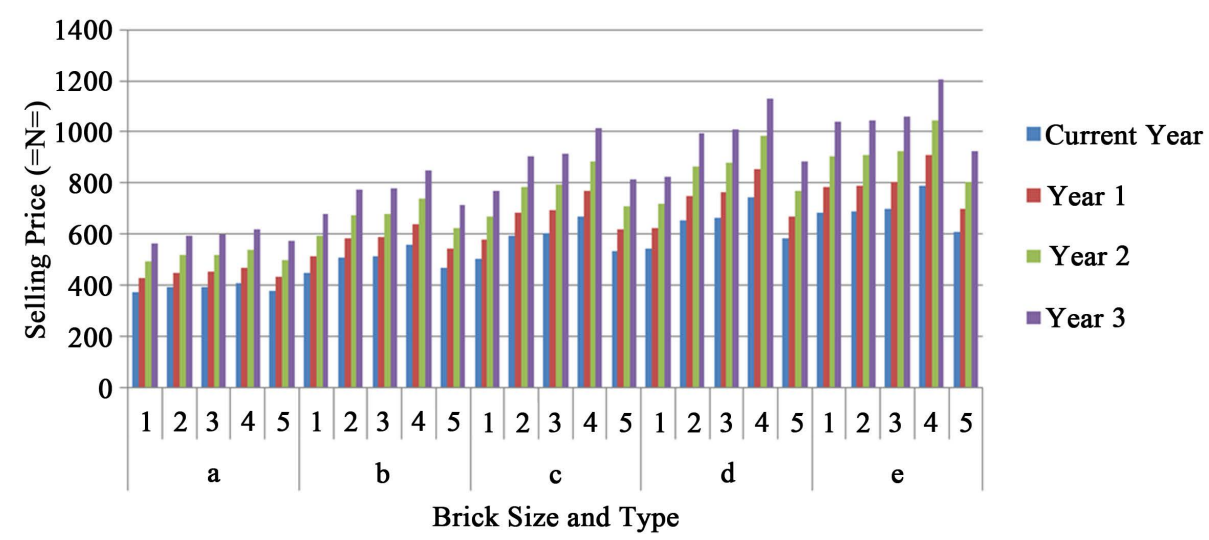

Figure 3. The estimation of the selling price of onibode fire-clay bricks based on three years projection at $15 \%$ inflation rate.

Type 1-9" × 21/4" × 21/2"; Type 2-9" × 31/2" × 21/2"; Type 3-9" × 41/2" × 2"; Type 4-9" × 41/2" × 21/2"; Type 5-9" $\times 41 / 2 " \times 11 / 2$ " and a, b, c, d, e-represent the total sum of the cost of materials for each types of bricks ( 1 - 5) respectively selected for the evaluation with the varying volume fraction of AL (from Table 3).

From the above analysis, refractory bricks produced from the low fire-clay grade have the least price of N426.76 for the first year and N564.39 in the third year (type "a" 1), while the highest price was N910.14 for the first year and N1,203.66 in the third year (type "e" 4) for the high grade fire-clay even as against the imported one of N1,800.00. CBA for the highest cost indicated that the project is worthwhile, because it has shorter payback period.

\section{Conclusion}

There is evidence of significant economic benefits of producing refractory bricks domestically. This includes among others: 1) the recovery of the investment capital within the shortest period of the investment; 2) provision of coverage for job creation; 3) acquisition of technological know-how; 4) the reduction of capital expenses on importation, etc. These benefits give an advantage to the domestically produced refractory bricks over the imported ones. The cost benefit analysis carried out indicated that the project was viable, as the highest cost for the brick produced locally was N1,203.66 (at three years projection) against the current N1,800.00 per one. The pay-back period of the investment is shorter. The analysis is capable of creating a platform for investment in the area of fire-clay refractory bricks production in Nigeria.

\section{References}

[1] Amuda, M.O.H., Lawal, G.I. and Majolagbe, F.O. (2005) Characterization of Some South West Clay Deposits. NSE Technical Transactions, 40, 13-23.

[2] Hassan, S.B. (2005) Effects of Silicon Carbide on Some Refractory Properties of Kankara Clay. Journal of Applied Science, Engineering and Technology, 5, 21-26.

[3] Apeh, F.I., Esezobor, D.E. and Lawal, G.I. (2010) Effect of Alumina Addition on the Refractoriness and Other Properties of Some Fire-Clays for Use as Furnace Lining. NSE Technical Transactions, 45, 26-35.

[4] Apeh, F.I. (2014) Enhancement of Refractory Characterization of Selected Nigerian Fire-Clays for Furnace Linings, Doctoral Thesis at the Department of Metallurgical and Materials Engineering, University of Lagos, Lagos, Nigeria.

[5] Nnuka, E.E., Ogo, D.U.I. and Elechukwu, J. (1992) Sustainable Refractory Sourcing of Our Industries. Proceedings of Annual Conference of NMS, Jos.

[6] Nnuka, E.E. and Adekwu, J.O. (1999) Refractory Characteristics of Kwi Clay Deposit in Plateau State. NSE Technical Transaction, 32, 35-39.

[7] Apeh, F.I., Esezobor, D.E. and Lawal, G.I. (2011) Characterization of Onibode and Owode-Ketu Fire-Clay for Use as Refractory Materials in Foundry Industry. Journal of Engineering Research, University of Lagos, 16, 69-77.

[8] Adeniyi, A.A. (2004) Management Accounting. 3rd Edition, Value Analysis Publishers, Lagos, 415-424. 
[9] Akinsulire, O. (2006) Financial Management. 4th Edition, Ceemol Nigeria Limited.

[10] ASTM C27-98 (2008) Standard Classification of Fireclay and High-Alumina Refractory Brick, Philadelphia.

[11] (2015) CBN Exchange Values of Naira. www.cenbank.org 